\title{
THE CONCEPT OF AN “OPEN SOCIETY” IN THE DEBATES OF THE 20TH CENTURY
}

\author{
Hanna Nikolenko \\ Postgraduate Student, H. Skovoroda Institute of Philosophy, Ukraine \\ e-mail: hannanikolenko@gmail.com,orcid.org/0000-0002-0973-3783
}

\section{Summary}

In the paper, the evolution of the concept of an "opened" society, which has been looking for a period from the middle of the XX century to the beginning XXI, is revealed. In the context of social and philosophical preliminaries, it is illustrated how the problem of openness is being shaped around the historical-philosophical and social-political issues. The reconstruction of the mechanisms of recognition, the transformation and development of the phenomenon of "openness" and the integration of the cultural and historical process have been built. In addition to the sensual, cultural, systematic approaches, the criteria of "openness" is conceptualized, on the basis of which the analysis of the current social concepts and the backward transformations of the spiritual tendencies of the human world are presented.

The paper presents the periodization of the concepts of "openness" in accordance with the changing of historical, philosophical and cultural and social context of the XX-XXI centuries. The specifics of the opposition of "open" and "closed" societies of A. Bergson on a number of specific features related to the stages of evolution of the mind: adaptation to circumstances, development of imagination, beginning of creativity, creation and self-reflection of one's own space (an activity beyond instinctive nature). It is emphasized that the idea of "openness" as "development" and "creativity" formed the basis of scientific analysis of further social transformations.

Keywords: open society, transformation, debates, conceptualization, historical retrospective, human values.

DOI: https://doi.org/10.23856/4029

\section{Introduction}

The paper proposes the conceptualization of the criteria of "openness" in the concept of K. Popper. The ways of implementation of social engineering as a mechanism of personal and social development are analyzed. It is traced how his methods are proposed as a way out of the social, humanitarian and ideological crisis of the military realities of the Second World War. The main ideas of step-by-step transformation became the foundation for further social and cultural transformations, as well as the method of "depreciation" to respond to the living conditions in the fleeting modern world (in the areas of social management, establishing new personal and social communication, domestic behavior, etc.).

The research shows the process of unfolding scientific reflection in accordance to changes in historical and social conditions. The periodization of the design and branching of socio-philosophical currents (every 10 years - a change or addition to the paradigm) is proposed and argued. Among the factors are: STR, political and economic revolutions, new domestic and social conditions of personal existence, global threats and the search for new worldviews. 
A historical retrospective is carried out in order to trace how the classical theories of A. Bergson and K. Popper are integrated into the historical and philosophical discourse of the 20 th century.

\section{First debates around "openness"}

The term "open society" was introduced in the work "Two sources of morality and religion" (1932) by A. Bergson. His ideas of "opened" and "closed" mind were developed in K. Popper's concept in the middle of the century. The most popular "open society" became after the publication in 1945 of K. Popper's work "Open Society and its enemies", in which he opposes totalitarian and democratic regimes. Since then, the concept has sparked numerous scientific debates as well as practical applications. After all, the ideas of openness are becoming universal values of the XXI century.

K. Popper's work “Open Society and Its Enemies” provoked a stormy reaction. Criticism and admiration of scholars concerned many elements of his concept: a completely new perception and even the debunking of such a majestic figure in philosophy as Plato; introduction of the method of falsification in science; a proposal to build a state without starting from the ideal, but with the help of scientific approaches; an outspoken statement of opposition to totalitarian regimes, and, at the same time, the lack of a direct link between the concept of "open society" and a particular political or economic philosophy. Each of these elements had responses in the scientific and political world. The first reaction was represented in a critical review by J. Meisel in 1950 and M. Brown in 1951. It was a general critique of the concept, a search for its strong and weak arguments and varied reflections on the problematic issues posed by the author. There is a correlation between humanitarian issues of wartime and postwar, adaptation to other living conditions, the search for peaceful stability and ways of diplomatic conflict resolutions. The threat of World War III background directs political activity in the direction of not forceful but intellectual organization of social processes, many studies are devoted to the nuances of this organization.

One of the first reactions of the book was also received in the field of theology, for example, T. Kook in the article "Philosophy and Religion: K. Popper" Open Society and its Enemies" and a review of M. Wallace" Book Review: Open "I", which was published as an interpretation for a journal of theology. The authors drew attention to the problem of K. Popper's comparison of freedom of choice of personality with opposition to higher authorities, including religious ones.

There were some attempts to adapt new ideas to some socially specific problems. An example is K. Scudder, who in 1954 devoted his article to the analysis of the then institutions of imprisonment in the context of possible transformations. In particular, he raised the issue of the concept of humanity, the revision of the attitude towards people in prisons, their rights to work, as well as adaptation after release (Scudder, 1954: 79-87). E. Price also devoted his work "Open Prisons and Public Safety" (1971) to this topic. It will be recalled that at that time it also widely applied to political prisoners, an issue that had no easy solutions and entailed the consequences of World War II.

In the 60's and 70's, the ideas of humanism began to shift “deep" into social transformations, there are psychological studies of human behavior depending on the type of activity and adaptation to production circumstances according to different types of societies. There are questions of humanism: the study of society's response to reforms aimed at openness (on the manifestations of violence, its causes and reactions to it). An analysis of reactions to reforms aimed 
at openness can be presented in the article by I. Ahmad "Closed thinking and open systems". Examples of psychological studies of behavior are the works of D. Lester, devoted to the manifestations of violence, its causes and reactions to it in society, including the article "Suicide and murder in open and closed societies" in 1971, as well as other essays depicting the dynamics of various types of thinking: G. Kemp "Critical thinking: open and closed mind", 1962; G. Aurora “Open systems of consciousness|", 1966; M. Richter "Other views on a closed society", 1974. There are also questions about the place of the media in the world of rapid technology. J. Murray devoted the article "Reardon's formula of the press: a threat to our open society", 1967, considering the press as a free institution from political pressure (Murray, 1967: 2-7). As we know, freedom of the press and journalistic investigations as part of public scrutiny play an important role in today's world.

Characteristics of the 70's are revealed in matters of public access to information, in particular the place of the media in the world of rapid technology. The authors also drew attention to the problem of comparing the freedom of choice of the individual as opposed to higher authorities, including religious ones. Aspects such as: the relationship with liberalism, the accuracy of scientific terminology and the controversy with Marxism were covered: environmental issues; worldviews: multiculturalism, identity, interracial mutual respect (A. Mazrui), psychological aspects: issues of personal freedom and responsibility (B. Crick, D. Spitz, A. Storr), as well as the possibility of transition from closed to open (M. Richter, K. Beime, E. Spinzhak, M. Sobolevsky); humanitarian aspect concerning educational perspectives and changes in the perception of work (L. Bramson). The features and advantages of closed and open societies, for example, by E. Parel and E. Owen, are being covered. Also relevant are the classical forms of criticism and rethinking the understanding of the criteria of openness (T. Settle, J. Jarvi, J. Agassi). These years have become especially fruitful in the context of rethinking the categories of "open society" in accordance with the new needs of today. In addition to this range of issues, the specifics of the transformations of the East towards openness were also highlighted, for example in the work of E. Cohn in 1970, "Turkish economic, social and political change: the development of a more prosperous and open society".

During the 1980s, the main directions of the synthesis of the idea of an "open society" were singled out. Aspects such as: the relationship with liberalism (the accuracy of scientific terminology and the controversy with Marxism); environmental issues; worldviews (multiculturalism, identity, interracial mutual respect); psychological aspects (issues of personal freedom and responsibility, as well as the possibility of transition from closed to open); humanitarian aspect concerning educational perspectives and changes in the perception of work were covered. Coverage of the features and benefits of closed and open societies continues. Classical forms of criticism and rethinking the understanding of openness criteria are also relevant. E. Parel compares "closed" / "open" worldviews in the 1982 article "Values of a closed society". Disputes over the attitude of the ideas of the "open society" to the democratic regime as an element of propaganda have become the most widespread. Some, especially the representatives of the socialist camp, tried to reduce this concept to a smaller element of the political struggle, as K. Popper himself in his introduction emphasized the struggle against this regime. On the other hand, Western researchers have observed that the ideas of "openness" are beginning to go beyond liberalism, and the values they proclaim are at odds with the realities of martial law. The search for a new paradigm begins: with attempts to more accurately define terminology, to suggest ways to transform it from a closed state to an open one, and to separate the "open society" from the political form, giving it supranational status in solving humanitarian and environmental problems. 


\section{Second wave of the debates}

In the 1990s, the situation in the political arena changed significantly: communist regimes were defeated, and Western democracies celebrated an ideological victory. These changes significantly influenced the development of the idea of an "open society": on the one hand, after the collapse of totalitarian regimes, societies needed change and were called "transforming", as if learning to be more open and build democratic institutions. On the other hand, largely based on opposition, the concept of "open society" was without the usual external enemy, and began to reassess the situation, choosing a new focus. Scholars have dispersed: some have turned to the internal contradictions of a "consumer society," others have focused on helping post-totalitarian countries, and others have begun to seek new landmarks, new forms of government, and solutions to global dangers.

Gradually, from the 90s of the twentieth century, with the expansion and assimilation of the concept of "openness" in accordance with modern society, the range of research became wider. Political changes have significantly influenced the development of the idea of an "open society": on the one hand, after the collapse of totalitarian regimes, societies needed a change and were called "transforming", as if they were "learning" to be more open and build democratic institutions. Ethical issues that are not as easily globalized as science and technology are gradually becoming urgent, and this is causing tensions at all levels of social interaction. The correlation of worldview foundations, adaptability and design of new industrial and domestic rules of conduct are increasingly important for the organization of human activity.

In her article "Minima Moralia: is there an ethics of the open society?" S. Pralong considers a range of ethical issues, which, first, were raised in the main work of K. Popper, and, according to the second, noted by the author as relevant and important for modern society (Pralong, 2005: 127). The 1990s were marked by the double victory of democracies over totalitarian systems of communism: the fall of the Berlin Wall and the collapse of the USSR. The abundance of new information about the state of social systems, as well as the influx of new experience - attempts to transform previous regimes into democracies, has provoked a number of critical questions about the categories of open society for countries where it is evolving and in new societies.

A study of Popper's understanding of the ideal types of "open and closed society" is offered by I. Jarvie in her article "Popper's ideal types: open and closed, abstract and concrete societies". I. Jarvie, analyzing the concept of K. Popper, notes that he was able to build an extremely fruitful interpretation of openness and secrecy, so much so that it shifted the focus of the debate of the twentieth century in political philosophy from democracy to openness. It should be noted at once that the author denies the existence of an "ideal society": there are no real societies in any of the open and closed poles. Instead, openness is the ideal; its achievement is largely relative" (Jarvie, 2005: 74). Thus, the modern West is a relatively open society. The openness lies in the fact that, first of all, a social space has been made for choosing and resolving disputes between the immutable laws of public life and man-made taboos: "this space we are trying to expand is an arena of personal responsibility, a social space where we are allowed it is encouraged to rationally evaluate choices, assessing their consequences, to decide and take responsibility for the result. Sometimes we can expand the space by changing the social framework. Openness allows us to be critical of choice and even of the social framework that restrains choice" (Jarvie, 2005: 75). Critical attitude here is identified with rationality. 
B. Magee offers his vision of the practical application of K. Popper's concept in the work "What use is Popper to a practical politician?" [154]. First of all, the author sees the fundamental attitude of people to imperfections and radical attempts to address social discontent. He notes that people tend to strive for the ideal type of society, and if some shortcomings are annoying, then there may be bursts of a revolutionary nature. As an example, he cites the revolutionary demonstrations of young people in the United States in 1989 demanding changes in the communist nature. Unaware of the realities of communist life, but dissatisfied with their own social injustice, young people seek change. An important mistake they make is the lack of correlation with reality, I want to cross everything out and start from scratch: "as the history of revolutions shows, today's society is never completely rejected: its huge and important features are always preserved in the hereditary society, disappointment and pity of revolutionaries" (Magee, 200: 145). As a result, we have four main consequences: 1) the death and terrible suffering of a large number of people; 2) not only undesirable, but also useful, active social tissue is destroyed; 3 ) large-scale violence is uncontrolled; 4) because of uncontrollability, revolutionaries do not get the type of society for which they started the revolution. And this, the author notes, is a person's behavior, a type of thinking “drawing the desired", and K. Popper's ideas - "antidote" for such illusions.

\section{Conclusions}

We have seen some trends in a criticism of the concept of "open society" change, while other trends remain. K. Popper's concept, from the moment of its appearance and all the time, has provoked numerous scientific debates; there were several attempts at a practical application. And although the exact meaning and form of an "open society" has never been decided, we can accurately outline its values, such as equality in social relations, a freedom of expression, cognition and language, and a transparency in decision-making and knowledge production. To re-assimilate the work of a government and a civil society new approaches were created on the base of "openness".

We described the effects of the idea of "openness" on various philosophical currents, traced the development of the debate for half a century, which had two main points of development, peaking in the $70 \mathrm{~s}$, adapting the concept to social realities, and 90 s associated with the emergence of countries in transition regimes and the need to reassess values within democracies that were left without a personal enemy and had to look inward. These processes are also characteristic of the first decades of the XXI century, but at the same time historical changes are taking place, which in a new way have actualized the issue of "openness". Globalization and the growing threat of terrorism are entering the arena, which again reincarnate the traditional notions of closed and open societies.

The dynamics of value, behavioral transformations of the ideas of "openness" in the socio-economic and cultural spheres, under the influence of technological and historical changes of the XX - early XXI centuries are traced. It is shown how the analysis of changing worldviews is integrated into modern social concepts (universalization of the ideas of "openness" as social values).

The paper demonstrates how "open" values are assimilated in the human world, becoming an important response mechanism in the process of creating a new type of society. The transition to a new type of civilization and methods of adapting the world to a self-created (autopoetic) society are presented in modern civilizational concepts and projects of new social architecture (models of social engineering embodied on the basis of technocratic transformations). 


\section{References}

Ahmad, I. (1966). Closed Minds and Open Systems. Sociological Bulletin. № 15, (2).

Aurora, G. S. (1966). Open Systems of Consciousness. Sociological Bulletin. № 15, (1).

Brown, M.R. (1951). Book Review: The Open Society and Its Enemies. Review \& Expositor. № 48, 2 .

Cohn, E.J. (1970). Turkish Economic, Social, and Political Change: The Development of a More Prosperous and Open Society. New York: Praeger.

Jarvie, I., Pralong, S. (2005). Popper's Open Society After Fifty Years. London: Taylor \& Francis e-Library.

Kemp, G.C. (1962). Critical Thinking: Open and Closed Minds. American Behavioral Scientist. №. 5 , (5).

Kook, T. (1951). Philosophy and Religion: Popper, Karl R. The Open Society and Its Enemies. The ANNALS of the American Academy of Political and Social Science. № 274, (1).

Lester, D. (1971). Suicide and Homicide in Open and Closed Societies. Psychological Reports. № 29, (2).

Magee, B. (2005). What use is Popper to a practical politician? Popper's Open Society After Fifty Years: The Continuing Relevance of Karl Popper. London: Taylor \& Francis e-Library.

Meisel, J.H. (1950). Book Reviews: The Open Society and Its Enemies. By KARL R. POPPER. Princeton: Princeton University Press.

Murray, J.E. (1967). The Reardon Press Formula: Threat to Our Open Society. The Journalism Educator. № 22, (4).

Pralong, S. (2005). Minima Moralia: is there an ethics of the open society? Popper's Open Society After Fifty Years: The Continuing Relevance of Karl Popper. London: Taylor \& Francis e-Library.

Price, E.T. (1971). Open Prisons and Public Safety. Australian \& New Zealand Journal of Criminology. № 4, (3).

Scudder, K.J. (1954). The Open Institution. The ANNALS of the American Academy of Political and Social Science. № 293, (1).

Wallace, M. (1950). Book Review: The Open Self. Union Seminary Magazine. № 4, (1).

Germino, D., Beyme, K. (1974). The Open Society in Theory and Practice. Hague: Martinus Nijhoff. 